\title{
A Case of 'All-or-None'? The Impact of Airline Travel On The Precocity And Severity of Covid-19 In Sub-National Areas Across 46 Countries
}

Ettore Recchi ( $\nabla$ ettore.recchi@eui.eu )

Sciences Po, Observatoire sociologique du changement (OSC)

Alessandro Ferrara

European University Institute

Alejandra Rodriguez Sanchez

Humboldt Universität

Emanuel Deutschmann

Europa-Universität Flensburg

Lorenzo Gabrielli

Joint Research Centre (JRC)

Stefano lacus

Joint Research Centre (JRC)

Luca Bastiani

Centro Nazionale delle Ricerche (CNR)

Spyridon Spyratos

Joint Research Centre (JRC)

Michele Vespe

Joint Research Centre (JRC)

\section{Research Article}

Keywords: travel, airports, mortality, network

Posted Date: November 3rd, 2021

DOl: https://doi.org/10.21203/rs.3.rs-967152/v1

License: (c) (i) This work is licensed under a Creative Commons Attribution 4.0 International License. Read Full License 


\section{Abstract}

Human travel fed the worldwide spread of Covid-19, but it remains unclear whether the volume of incoming air passengers and the centrality of airports in the global airline network made some regions more vulnerable to earlier and higher mortality. We assess whether the precocity and severity of Covid-19 deaths were contingent on these measures of air travel intensity, controlling for differences in local non-pharmaceutical interventions and pre-pandemic structural characteristics of 503 sub-national areas on five continents in April-July 2020. OLS models of precocity (i.e., the timing of the $1^{\text {st }}$ and $10^{\text {th }}$ death outbreaks) reveal that the volume of incoming passengers and the centrality of airports were not impactful once we controlled for local characteristics. We model severity (i.e., the weekly death incidence of Covid-19) with both GLMM and OLS regressions. Results suggest that death incidence was insensitive to the number of passengers and airport centrality, with no substantial changes over time. However, total travel bans did reduce mortality significantly. We conclude that Covid-19 importation through air travel followed an 'All-or-None' principle: it contributed to mortality at all times but not proportionally to the number of incoming passengers nor the position of airports in the global network of travel.

\section{Introduction}

That 'travel is a potent force in disease emergence and spread' is a mainstay of public health research ${ }^{1}$. Epidemics are multi-scale network phenomena that hinge on human mobility as a source of contacts across social contexts ${ }^{2}$. In a cascade-like process, long-distance travel is first understood to trigger local outbreaks. Consequently, population mixing propagates the disease locally. Eventually, local fatality is conditional upon sociodemographic and health-related predispositions to a higher incidence.

Research on the spread of Covid-19 has rarely considered simultaneously these three types of factors - longdistance travel, population mixing, and structural predispositions ${ }^{3,4}$. Our focus is on the role of the first factorlong-distance travel, which diminished but did not halt in 2020. It also controls for the two other types to account for differences in the timing and the impact of the disease across localities. We assess whether the precocity and severity of the Covid-19 pandemic in the first half of 2020 was contingent on the volume of airline passenger inflows, the position of airports in the global network of commercial flights, and travel reduction policies. We do so dynamically with weekly data and taking sub-national areas as our research units. This allows us to study the impact of airline passengers at a higher granularity than most existing studies that have only examined it at the more coarse-grained national level. At the same time, this granularity makes our models more sensitive to local variations in non-travel related drivers of the pandemic. Such variations may be especially important in larger and more diverse countries, where the national average can overshadow diverse area risks. This is sometimes highlighted as a serious limitation of existing comparative studies ${ }^{5}$.

Before the Covid-19 pandemic, research delved into modelling the relationship between the characteristics of the global travel network - relying mostly on airline travel, as we do in the following - and the timeline of the spread of epidemics ${ }^{6}$. These studies have especially leveraged the inherent network properties of transportation infrastructures, which are in turn an instance of larger interconnected socio-technical systems ${ }^{7}$ that are independent of the characteristics of specific diseases and other possible human and environmental covariates ${ }^{8}$. To widen the picture, the critical nature of international routes has been interplayed with local mobility 
parameters, in particular commuting, showing that the latter has a stronger impact on the spread of epidemics in the periphery of the global travel network ${ }^{9}$. Similarly, several studies prove that limits to personal interactions at the local level reduce overall epidemic prevalence much more than reduced long-haul travel does, unless travel restrictions are very timely and drastic ${ }^{10,11,12}$. A study on the effect of pre-existing levels of international travel on the evolution of the 1889, 1918, 1957 and 2009 pandemics found that even extremely large historical variations in global mobility (from the late 19th century to the early 21 st century) only affected the speed of the crosscountry transmission of pandemics minimally ${ }^{13}$. The same study shows that final mortality rates by country are statistically independent from the time of the outbreaks in these pandemics.

The Covid-19 pandemic has fostered a proliferation of research on the impact of travel on the timeline and spatial spread of the virus since its early manifestation in the Wuhan region. Early studies have mostly a single country or regional scope and suffer from data limitations - most noticeably, they are restricted timewise. Such studies show a strong correlation between the number of cases and prior incoming air passenger volume, both across Chinese areas and countries ${ }^{14,15,16,17}$. However, the reliability of case detection - especially in the very early stages of the epidemic (i.e., the first quarter of 2020) - is highly questionable, depending on the availability of tests and the propensity of the population to be screened, which varied considerably from one country to another. With a longer time perspective, other models show that even with a 90 percent travel reduction from the epicenter of the pandemic - that is, mainland China - transmission would have occurred ${ }^{18,19}$. Although air traffic limitation is not decisive in reducing the eventual impact of the disease, it was shown to 'buy time' in the early phase of the pandemic, which may be critical in setting up adequate health responses ${ }^{20,21,22}$. In May 2020, imported cases accounted for between 1 and 10 percent of total cases in two thirds of countries ${ }^{23}$. The bottom line of these early studies on the nexus between long-distance mobility and the spread of Covid-19 is perhaps best epitomized as follows: 'travel restrictions might be an effective measure in the short term, however [..] they are ineffective when it comes to completely eliminat[ing] the disease 24 .

Drawing on this literature, we formulate and test three hypotheses. The first hypothesis is about the precocity of Covid-19 outbreaks:

H1) Areas with larger airline travel volume and higher connectedness experienced earlier outbreaks of Covid-19 (the 'travel as timer' hypothesis).

The second and third hypotheses refer to the severity of Covid-19 impact:

$\mathrm{H} 2$ ) Areas with larger airline travel volume and higher connectedness experienced a stronger incidence of Covid19 , and even more so in the case of a larger gradient in incidence between travel origin and destination (the 'travel as fuel' hypothesis);

H3) Over time, air travel volume and connectedness had a diminishing importance on the incidence of Covid-19, since importation was progressively contained by NPIs, while population mixing and structural factors brought about differences in mortality between localities (the 'travel as spark' hypothesis).

Our timeframe is the period April-July 2020, following the WHO's declaration of the Covid-19 pandemic, and the occurrence of the first wave in most parts of the planet. Eventually, our findings align with $\mathrm{H} 1$ only very partially, as the centrality of destination airports in the global network of flights is not a significant predictor of earlier outbreaks, nor is the volume of air passengers, once we control for structural factors in receiving areas. $\mathrm{H} 2$ is also 
not corroborated but rather qualified, highlighting that the impact of long-distance mobility is particularly dependent on travel bans. In fact, $\mathrm{H} 3$ is falsified, as no trend in the impact of air travel on Covid-19 death incidence is detected given variations in travel limitation policies.

\section{Data And Methods}

The analyses presented in this article are based on the novel Sub-National Covid-19 Incidence and Determinants Dataset, which includes 503 sub-national areas of 46 countries in five continents (Europe, Asia, North America, South America and Oceania). The information used to build this dataset was drawn from a variety of sources in order to cover four major areas of interest: health outcomes of the pandemic (Covid-19 cases and deaths), air travel variables (number of incoming air passengers from China and other origins, centrality of local airports in the global airline network, air travel limitation policies), population mixing and NPIs (based on the Oxford-tracker stringency index), and pre-pandemic area characteristics (socioeconomics, demographics, public health and prior mortality rates). Details on the sources and the variables can be found in the accompanying document of the dataset. All data came from public sources, with the exception of information on passenger volume and airport centrality, which we were authorized to draw from Sabre Travel Data, a private company dataset on airport traffic collected directly from the airline industry (https://www.sabre.com). These data were further processed and aggregated by areas in our dataset. In this article we model the precocity (i.e., the calendar week of the $1 \mathrm{st}$ and 10th Covid-19 deaths) and severity (i.e., the weekly Covid-19 number of deaths per capita) of Covid-19 through OLS and negative binomial regressions, respectively. To strengthen our findings, we draw on a plethora of model specifications controlling for variables that were found to affect the outcome significantly in previous research (see Results section).

\section{Results}

\section{Precocity of Covid-19 outbreaks}

In this section, we test whether the precocity of the outbreaks of the epidemic could be predicted on the basis of the inflows of airline passengers from the hotbed of Covid-19 (mainland China) or through other air travel routes. In Table 1 we focus on the calendar week of occurrence of the first death in our sample, which ranges from 7 (second week of February 2020, in Southern Canto, Japan) to 23 (last week of May 2020, in New Brunswick, Canada). We estimate models that include passenger volume from Chinese airports and from other world airports separately (tables 1A and 1B) to avoid collinearity issues since the two figures are strongly correlated $(r=60)$. As a sensitivity check, we also repeat the analysis for the week of occurrence of the 10th Covid-19 death (Models 5-8). Negative coefficients indicate an earlier outbreak. Models 1 and 5 in Table 1 are estimated with mobility-related variables only. The volume of incoming passengers from flights originating from China and from other world airports is prima facie significant, while the area's network centrality in global air traffic is not. Passenger volume is no longer impactful once we take into account population size, which substantially increases the likelihood of having a Covid-19 outbreak earlier, as well as population density and GDP per capita (models 2, 3 and 7). Demographic and health characteristics - in particular, a larger senior population and a higher prevalence of obesity - appear to amplify the likelihood of mortality at the onset of the epidemic (models 4 and 8). These effects are quite similar whether we estimate them in conjunction with the volume of passengers from China or from the rest of the world. Interestingly, pre-pandemic cardiovascular and cancer death rates are in 
fact inversely related to the precocity of the onset of Covid-19 deaths, possibly because areas with a higher incidence of these diseases are more prepared to tackle medical emergencies. Equally, a larger availability of hospital beds - which is likely to attest more broadly to the strength of the health system - also counters an earlier spread up to the 10 th recorded death.

The same analyses were repeated with the occurrence of the 1st and 10th Covid-19 cases - which are known to be less reliable indicators of the outbreak than death counts, due to different testing and recording efforts across countries. We obtained similar results, although with stronger effects for the volume of passengers (see Supplementary information). We also found that these results were robust to the exclusion of different countries. Four of our sub-national areas are outliers (two in Japan, two in the US), as they receive an extremely high number of air passengers (from China or from the rest of the world, respectively) while having a relatively late occurrence of Covid-19 deaths. If we exclude these areas, the effects of incoming air passengers are larger, but still not significant once we control for all other covariates in our models (see Supplementary information).

On balance, we have to nuance $\mathrm{H} 1$ (the 'travel as timer' hypothesis). The risk of experiencing an earlier outbreak of Covid-19 deaths is not conditional on airport centrality. The volume of incoming passengers (from China and elsewhere) is at best no more than a concomitant cause with a larger, older, and overweight population - and possibly the randomness of the distribution of a few super-spreaders in the global network of long-distance travels.

Table 1. The impact of late 2019 air passenger traffic on the precocity of Covid-19 outbreaks (occurrence of 1st and 10th death) [1A: traffic from Chinese airports; 1B: traffic from other airports]. OLS regressions without and with continent fixed effects

1A. Airline passengers from Chinese airports 


\begin{tabular}{|c|c|c|c|c|c|c|c|c|}
\hline & (1) & (2) & (3) & (4) & (5) & (6) & (7) & (8) \\
\hline & Wk 1st & Wk 1st & Wk 1st & Wk 1st & $\begin{array}{l}\text { Wk } \\
10 \text { th }\end{array}$ & Wk 10th & Wk 10th & Wk 10th \\
\hline \multirow{2}{*}{$\begin{array}{l}\text { Inbound Chinese } \\
\text { passengers pc } \\
\text { (end of 2019) }\end{array}$} & $-0.542^{\star *}$ & 0.042 & -0.240 & -0.043 & -0.567 & 0.573 & -0.042 & -0.409 \\
\hline & $(0.175)$ & $(0.204)$ & $(0.185)$ & $(0.181)$ & $(0.348)$ & $(0.386)$ & $(0.367)$ & $(0.358)$ \\
\hline \multirow{2}{*}{$\begin{array}{l}\text { Airport centrality } \\
\text { (end of 2019) }\end{array}$} & -0.156 & -0.097 & 0.092 & 0.040 & -0.289 & -0.068 & 0.149 & 0.086 \\
\hline & $(0.191)$ & $(0.192)$ & $(0.168)$ & $(0.158)$ & $(0.380)$ & $(0.363)$ & $(0.331)$ & $(0.309)$ \\
\hline \multirow[t]{2}{*}{ Population } & & $-2.917^{\star \star \star}$ & $-3.183^{\star \star \star}$ & $-2.843^{\star \star \star}$ & & $-5.143^{\star \star \star}$ & $-4.720^{\star \star \star}$ & $-4.443^{\star \star \star}$ \\
\hline & & $(0.618)$ & $(0.579)$ & $(0.553)$ & & (1.185) & $(1.153)$ & $(1.091)$ \\
\hline \multirow{2}{*}{$\begin{array}{l}\text { Population } \\
\text { density (pop per } \\
\mathrm{km}^{2} \text { ) }\end{array}$} & & -0.373 & -0.243 & -0.349 & & -0.714 & -0.710 & $-0.884^{*}$ \\
\hline & & $(0.215)$ & $(0.187)$ & $(0.179)$ & & $(0.410)$ & $(0.371)$ & $(0.353)$ \\
\hline \multirow[t]{2}{*}{$\begin{array}{l}\text { Real GDP pc } \\
\text { PPP }\end{array}$} & & $-0.420^{* *}$ & 0.026 & 0.164 & & $-1.954^{\star \star \star}$ & $-0.599^{*}$ & -0.365 \\
\hline & & $(0.134)$ & $(0.129)$ & $(0.129)$ & & $(0.289)$ & $(0.302)$ & $(0.307)$ \\
\hline \multirow[t]{2}{*}{$\begin{array}{l}\text { Hospital beds } \\
\text { per } 1000\end{array}$} & & & & 0.117 & & & & $1.482^{* \star}$ \\
\hline & & & & $(0.264)$ & & & & $(0.518)$ \\
\hline \multirow[t]{2}{*}{ Share of $65+$} & & & & $-0.711^{\star \star \star}$ & & & & $-1.385^{\star \star \star}$ \\
\hline & & & & $(0.181)$ & & & & $(0.371)$ \\
\hline \multirow{2}{*}{$\begin{array}{l}\text { Cardiovascular } \\
\text { age- } \\
\text { standardized } \\
\text { death rate }\end{array}$} & & & & $0.978^{\star \star \star}$ & & & & 0.584 \\
\hline & & & & $(0.260)$ & & & & $(0.535)$ \\
\hline \multirow{2}{*}{$\begin{array}{l}\text { Cancer age- } \\
\text { standardized } \\
\text { death rate }\end{array}$} & & & & $0.490^{*}$ & & & & $1.642^{\star \star \star}$ \\
\hline & & & & $(0.198)$ & & & & $(0.398)$ \\
\hline
\end{tabular}

Standard errors in parentheses

${ }^{*} p<0.05,{ }^{* *} p<0.01,{ }^{* \star} p<0.001$

Source: Sub-National Covid-19 Incidence and Determinants Dataset 


\begin{tabular}{|c|c|c|c|c|c|c|c|c|}
\hline & (1) & (2) & (3) & (4) & (5) & (6) & (7) & (8) \\
\hline \multirow{2}{*}{$\begin{array}{l}\text { Prevalence of } \\
\text { adult obesity }\end{array}$} & & & & -0.773 & & & & $-3.572^{\star \star \star}$ \\
\hline & & & & $(0.396)$ & & & & $(0.795)$ \\
\hline Observations & 439 & 439 & 439 & 439 & 416 & 416 & 416 & 416 \\
\hline R-squared & 0.048 & 0.133 & 0.359 & 0.444 & 0.018 & 0.192 & 0.353 & 0.448 \\
\hline $\begin{array}{l}\text { Continent Fixed } \\
\text { Effects }\end{array}$ & No & No & Yes & Yes & No & No & Yes & Yes \\
\hline \multicolumn{9}{|c|}{ Standard errors in parentheses } \\
\hline \multicolumn{9}{|c|}{${ }^{*} p<0.05,{ }^{* \star} p<0.01,{ }^{\star \star \star} p<0.001$} \\
\hline Source: Sub-Nati & al Covic & Incider & nd Dete & lants $\mathrm{Da}$ & & & & \\
\hline
\end{tabular}

1B. Airline passengers from non-Chinese airports 


\begin{tabular}{|c|c|c|c|c|c|c|c|c|}
\hline & (1) & (2) & (3) & (4) & (5) & (6) & (7) & (8) \\
\hline & Wk 1st & Wk 1st & Wk 1st & Wk 1st & Wk 10th & Wk 10th & Wk 10th & Wk 10th \\
\hline \multirow{2}{*}{$\begin{array}{l}\text { Inbound non- } \\
\text { Chinese } \\
\text { passengers pc } \\
\text { (end of 2019) }\end{array}$} & $-0.764^{\star \star \star}$ & -0.064 & 0.032 & -0.078 & $-1.549^{\star \star \star}$ & 0.093 & 0.095 & 0.647 \\
\hline & $(0.134)$ & $(0.221)$ & (0.195) & $(0.193)$ & $(0.265)$ & $(0.427)$ & (0.389) & $(0.382)$ \\
\hline \multirow{2}{*}{$\begin{array}{l}\text { Airport } \\
\text { centrality (end } \\
\text { of 2019) }\end{array}$} & -0.289 & -0.078 & -0.021 & 0.021 & -0.198 & 0.229 & 0.132 & -0.095 \\
\hline & $(0.151)$ & $(0.162)$ & $(0.143)$ & $(0.136)$ & $(0.297)$ & $(0.306)$ & $(0.281)$ & $(0.265)$ \\
\hline \multirow[t]{2}{*}{ Population } & & $-2.664^{\star \star \star}$ & $-3.718^{\star \star \star}$ & $-2.685^{\star \star \star}$ & & $-4.401^{\star *}$ & $-5.064^{\star \star \star}$ & $-7.018^{\star \star \star}$ \\
\hline & & $(0.801)$ & $(0.721)$ & $(0.730)$ & & (1.529) & $(1.424)$ & (1.438) \\
\hline \multirow{2}{*}{$\begin{array}{l}\text { Population } \\
\text { density (pop } \\
\text { per } \mathrm{km}^{2} \text { ) }\end{array}$} & & -0.366 & -0.244 & -0.339 & & -0.736 & -0.720 & $-0.955^{* *}$ \\
\hline & & $(0.217)$ & (0.190) & $(0.181)$ & & $(0.414)$ & $(0.374)$ & $(0.355)$ \\
\hline \multirow{2}{*}{$\begin{array}{l}\text { Real GDP pc } \\
\text { PPP }\end{array}$} & & $-0.406^{* *}$ & 0.0113 & 0.178 & & $-1.988^{\star \star \star}$ & -0.628 & -0.552 \\
\hline & & $(0.143)$ & $(0.134)$ & $(0.133)$ & & $(0.314)$ & (0.319) & $(0.322)$ \\
\hline \multirow{2}{*}{$\begin{array}{l}\text { Hospital beds } \\
\text { per } 1000\end{array}$} & & & & 0.108 & & & & $1.550^{\star \star}$ \\
\hline & & & & $(0.264)$ & & & & $(0.518)$ \\
\hline \multirow[t]{2}{*}{ Share of $65+$} & & & & $-0.713^{\star \star \star}$ & & & & $-1.383^{\star \star \star}$ \\
\hline & & & & $(0.181)$ & & & & $(0.370)$ \\
\hline \multirow{2}{*}{$\begin{array}{l}\text { Cardiovascular } \\
\text { age- } \\
\text { standardized } \\
\text { death rate }\end{array}$} & & & & $0.981^{\star \star \star}$ & & & & 0.614 \\
\hline & & & & $(0.259)$ & & & & $(0.532)$ \\
\hline \multirow{2}{*}{$\begin{array}{l}\text { Cancer age- } \\
\text { standardized } \\
\text { death rate }\end{array}$} & & & & $0.484^{\star}$ & & & & $1.609^{\star \star \star}$ \\
\hline & & & & (0.197) & & & & $(0.395)$ \\
\hline
\end{tabular}

Standard errors in parentheses

${ }^{*} p<0.05,{ }^{* *} p<0.01,{ }^{* \star} p<0.001$

Source: Sub-National Covid-19 Incidence and Determinants Dataset 


\begin{tabular}{|c|c|c|c|c|c|c|c|c|}
\hline & (1) & (2) & (3) & (4) & (5) & (6) & (7) & (8) \\
\hline \multirow{2}{*}{$\begin{array}{l}\text { Prevalence of } \\
\text { adult obesity }\end{array}$} & & & & -0.724 & & & & $-3.664^{\star \star \star}$ \\
\hline & & & & $(0.399)$ & & & & $(0.795)$ \\
\hline Observations & 439 & 439 & 439 & 439 & 416 & 416 & 416 & 416 \\
\hline R-squared & 0.094 & 0.133 & 0.357 & 0.444 & 0.088 & 0.188 & 0.354 & 0.451 \\
\hline $\begin{array}{l}\text { Continent } \\
\text { Fixed Effects }\end{array}$ & No & No & Yes & Yes & No & No & Yes & Yes \\
\hline \multicolumn{9}{|c|}{ Standard errors in parentheses } \\
\hline \multicolumn{9}{|c|}{${ }^{*} p<0.05,{ }^{* *} p<0.01,{ }^{* \star *} p<0.001$} \\
\hline Source: Sub-N & onal Co & 9 Incide & and Det & inants $D$ & & & & \\
\hline
\end{tabular}

\section{Modeling the severity of Covid-19 deaths in April-July 2020}

Although travel limitations were pervasive as a first defense against the spread of the new virus, air traffic was not completely stopped in the wake of the pandemic. Our dataset includes information on the number of incoming passengers along all flight routes. The bulk of them diminished drastically after March 2020. Radical drops - with the full cancellation of routes - affected Asia particularly (Figures 1A [April 2019] and 1B [April 2020]). Globally, the drop in the volume of passengers was dramatic (Figure 1C). At its lowest, in May 2020, the number of air passengers was 12 percent of the corresponding 2019 figure and until July 2020 it had recovered to no more than 34 percent. In May 2020, only 3 percent of routes had not experienced any decline in air passengers compared to the same month one year earlier (Figure 1D). However, air traffic was not entirely cancelled, as Figure 1B shows. Some passengers continued to move between most parts of the globe. Potentially, this might have led to higher incidence of the disease where larger numbers of incoming travelers continued to arrive, especially if their origin was from highly infected zones. Therefore, we not only model the impact of the number of incoming air passengers (per capita) on the receiving areas' incidence of Covid-19 between April and July 2020, but also the interaction between this variable and the average incidence of the disease in the sending areas (Tables 2, 3 and 4).

Together with long-distance mobility, other factors are known to boost heterogeneity in the lethality of the pandemic across locations. Previous research on between-country variations in Covid-19 severity has consistently highlighted the effect of several pre-existing comorbidities including a senior population structure, a higher GDP per capita and a lower number of hospital beds ${ }^{25,26}$. The impact of population density, obesity and air pollution is empirically less clear, with some within-country ecological studies disproving their independent impact on Covid-19 mortality 27,28 . We include these potential predictors in the following analyses as Structural predispositions, with the only exception of air pollution, for which we have 20 percent missing cases (analyses including this variable are in the Supplementary information). There is also strong evidence that everyday human interactions are highly conducive to the spread of Covid-19 - and their reduction conversely reduces contagion 5,29,30,31. We operationalized such Population mixing through the 'Oxford-tracker modified stringency index' of NPIs, lagged by three weeks ${ }^{32}$. Given that basically all forms of NPIs aim for a reduction of human 
interactions, we deem this single indicator to be the most parsimonious way of tapping changes in population mixing over time. This is also in light of research based on mobile positioning data that indicates overall compliance with such measures in the first semester of $2020^{33}$. The index is modified by removing its international travel limitation component, as this is included among our covariates separately. Our core variables revolve around Long-distance mobility. air passenger volume per capita (lagged by one month), the average incidence in the sending regions of these passengers (lagged by one month), the centrality of the subnational area in the global network of commercial flights (lagged by one month), and the air travel restriction policy that was in place three weeks earlier. Air travel restriction policies are operationalized in three categories: total travel ban as a baseline, travel bans for some routes, and less disruptive limitations (like temperature-screening, or quarantines for incoming passengers, or no limitations at all). In a separate analysis, we replace travel restrictions with actual passenger drop (through the dummy variable used in Figure 1D: decline of more than 10 percent of travelers compared to one year earlier). Such a specification simulates a sort of counterfactual scenario in which travel continued in spite of the pandemic (see Supplementary information). Lags of three weeks are introduced assuming, from existing literature, an average Covid-19 infection-to-death delay of 20-23

days. ${ }^{34,35}$ We extended the lag to one month for our travel indicators given their monthly nature. Finally, we introduced a variable that accounts for Recursive effects - namely the calendar week of the first Covid-19 death (which was the dependent variable in Table 1). This factor incorporates what has been called the 'surprise effect' of Covid-19, as a sooner outbreak could bring about a less efficient public health response ${ }^{36}$.

\section{Weekly incidence: A generalized mixed model specification}

In this section, we test $\mathrm{H} 2$ (the 'travel as fuel' hypothesis) on the impact of airline mobility by estimating a generalized mixed model (or multilevel model) which allows us to pool together all weekly information for the April-July 2020 period. Mixed models adjust for the nested data structure of our sub-national areas within countries, also taking into account the fact that we have longitudinal measures. In other words, each week for which we have data on deaths (level 1 ) is nested within each of the sub-national areas (level 2), which themselves are nested within countries (level 3) and within continents (level 4). By adjusting for time-based change, we can factor out heterogeneities in individual sub-national areas, as well as other existing heterogeneities between countries and continents ${ }^{37}$. Our specification also includes a time predictor (i.e., calendar week), as well as time-varying and time-invariant predictors. We fit a generalized linear mixed-effects model (GLMM) for the negative binomial family to our data with a random intercept and slope for the time indicator (calendar week). We assume a known overdispersion parameter of 1.2 (results do not vary much for other choices of the parameter; available upon request). One advantage of this approach is that it models changes over time at the local level simultaneously (e.g., how fast the pandemic evolves) and differences in timewise change across different areas (e.g., differences in the peaks and valleys of the pandemic).

Table 2 reports the interaction between each of the dynamic variables (i.e., related to long-distance mobility and population mixing) and calendar week (for a stepwise version of the models, see Supplementary information). When interacting with time, the estimated risk ratios for long-distance mobility variables are close to zero. In fact, the effects of minimal travel bans (Model 1, Table 2) or no drops in passenger inflows (Model 2, Table 2) as opposed to full travel bans are above one. This attests to some impact on the severity of the pandemic, but not to a statistically significant level. Structural predispositions to the virus incidence - particularly, population size, GDP per capita, the age structure of the population, as well as the paucity of hospital beds, cancer-risk and obesity (albeit these are not significant statistically) - have a definitively greater bearing on the incidence of the 
disease. As expected, NPIs other than travel limitations mitigate the pandemic significantly. The precocity of the outbreaks is confirmed to be a strong and significant predictor of its subsequent severity. Finally, the estimated random intercepts and slopes from both models suggest that the higher levels (i.e., countries and continents) explain the total variance in weekly deaths more than the lower sub-national areas. 
Table 2

The impact of air passenger traffic on the severity of Covid-19 mortality in April-July 2020, controlling for population mixing (NPI), structural predispositions and recursive effects. Generalized linear mixed-effects models

\section{Model 1}

$\begin{array}{ll}\text { Risk } & \begin{array}{l}\text { Confidence } \\ \text { intervals }\end{array} \\ \text { Ratio } & \end{array}$

\section{Model 2}

$\begin{array}{ll}\text { Risk } & \begin{array}{l}\text { Confidence } \\ \text { intervals }\end{array} \\ \text { ratio } & \end{array}$

\section{Long-distance mobility (interacted by}

calendar week)

\begin{tabular}{lcccc}
$\begin{array}{l}\text { Incidence in sending region } \mathrm{x} \text { inbound } \\
\text { passengers }\end{array}$ & 1.001 & {$[0.986-1.015]$} & 0.999 & {$[0.984-1.014]$} \\
\hline Airport centrality (lag 1 month) & 1.002 & {$[0.991-1.012]$} & 1.001 & {$[0.991-1.012]$}
\end{tabular}

Travel restrictions (ref: total travel ban)

\begin{tabular}{lllll}
$\begin{array}{l}\text { At most screening and quarantine (lag } 3 \\
\text { weeks) }\end{array}$ & 1.052 & {$[0.993-1.115]$} & - & - \\
Partial travel ban (lag 3 weeks) & 1.027 & {$[0.986-1.070]$} & - & - \\
\hline No drop in passengers compared to 2019 & - & - & 1.016 & {$[0.980-1.055]$}
\end{tabular}

Population mixing (interacted by calendar week)

Modified Stringency Index (lag 3 weeks) $\quad 0.977^{\star \star \star} \quad[0.974-0.987] \quad 0.975^{\star \star \star} \quad[0.968-0.981]$

Structural predispositions

Population size (residents)

$1.878 * \star \star \quad[1.627-2.168] \quad 1.882^{\star \star \star} \quad[1.631-2.171]$

Real GDP pc PPP

$1.329 * \star \star \quad[1.135-1.556] \quad 1.313^{\star \star \star} \quad$ [1.122-1.538]

Population density (pop per $\mathrm{km}^{2}$ )

$0.991 \quad[0.832-1.18] \quad 0.985 \quad$ [0.828 - 1.172]

Hospital beds per 1000 residents

0.637 [0.348-1.166] $0.628 \quad$ [0.344-1.146]

Share of population aged 65+

\begin{tabular}{|c|c|}
\hline $1.744 * \star \star$ & [1.346 - 2.26] \\
\hline
\end{tabular}

Cardiovascular age-standardized death rate

0.765

[0.431 - 1.357]

0.946

[0.54 - 1.657]

Cancer age-standardized death rate

1.176

[0.760 - 1.820]

1.177

[0.752 - 1.842]

Prevalence of adult obesity

1.388

[0.656 - 2.938]

1.412

[0.644 - 3.100]

Recursive effects

Week of first COVID death

$\underset{* \star \star}{0.588}$

[0.531 - 0.651]

$0.587 * \star \star$

[0.644 - 0.650]

Observations

4,970

4,970

Random Intercepts: Variance (std)

${ }^{\star} p<0.05,{ }^{*}{ }^{\star} p<0.01,{ }^{* \star *}{ }^{\star} p<0.001$. Note: the model controls for the main effects of all listed variables.

Source: Sub-National Covid-19 Incidence and Determinants Dataset 


\begin{tabular}{|llc|}
\hline \multicolumn{2}{|c|}{ Model 1 } & Model 2 \\
\hline Nuts / Country / Continent & $2.923(1.710)$ & $2.770(1.664)$ \\
\hline Country / Continent & $3.102(1.761)$ & $3.888(1.971)$ \\
\hline Continent & $6.315(2.513)$ & $1.278(11.303)$ \\
\hline Random Slopes: Variance (std) & & \\
\hline Nuts / Country / Continent & $0.007(0.086)$ & $0.007(0.085)$ \\
\hline Country / Continent & $0.021(0.146)$ & $0.021(0.145)$ \\
\hline Continent & $0.022(0.151)$ & $0.722(0.850)$ \\
\hline Log Likelihood & $-16,719.050$ & $-16,743.310$ \\
\hline Akaike Inf. Crit. & $33,508.090$ & $33,551.620$ \\
\hline Bayesian Inf. Crit. & $33,753.990$ & $33,767.490$ \\
\hline \multirow{2}{*}{$p<0.05, \star^{*} p<0.01, * * *^{*} p<0.001$. Note: the model controls for the main effects of all listed variables. } \\
\hline Source: Sub-National Covid-19 Incidence and Determinants Dataset
\end{tabular}

\section{Weekly incidence: Modeling months separately}

This section presents an alternative modeling strategy. Our dependent variable is still weekly incidence (Covid-19 deaths per capita), but we concentrate on the first weeks of April, May, June and July 2020. With this analysis we aim to check the robustness of the multilevel models discussed in the previous section, and at the same time dig deeper into the time-specific impact of different factors in the first four months of the pandemic, thus testing $\mathrm{H} 3$ (the 'travel as spark' hypothesis).

Table 3 reports the full models for the first week of each month. The severity of Covid-19 mortality in receiving areas was not significantly impacted by the number of incoming passengers, nor the risk associated with them coming from areas with higher incidence (measured through an interaction factor), nor airport centrality. Travel restrictions, however, did matter. Up until June, areas which imposed at best mild restrictions (such as screening passengers or quarantining them) fared worse than areas that took a stricter approach. Partial travel bans proved as effective as full bans in the early months (or even more in May), but significantly less in June and July, possibly because route triangulation bypassed them over time.

As for controls, their effect is not always as expected or significant. In particular, the lagged Oxford stringency index (modified in order to exclude travel policies, which we considered separately, like in the prior section) was found to associate positively with the severity of the pandemic. A possible explanation is reverse causality: stricter measures against population mixing had to be taken in areas with rising Covid-19 mortality. This is still the case with the 3-week lagged version of this variable, which is included in the model. More hospital beds are associated with a lower Covid-19 mortality at all stages, while GDP per capita and population size boost incidence. The precocity of Covid-19 outbreaks is a constantly significant predictor of higher mortality at all points of our series. Interestingly, with these controls, areas with a larger senior population have slightly (but not significantly) lower incidence in the observed months. Population obesity is a strongly significant predictor in 
April, but its effect declines and even reverts at the end of our period of observation. In contrast, areas with higher levels of cardiovascular mortality face a progressively increasing incidence. 
Table 3

The impact of air passenger traffic on the severity of Covid-19 mortality in April-July 2020, controlling for population mixing (NPI), structural predispositions and recursive effects. Negative binomial regressions with continent fixed effects. Risk ratios and confidence intervals (in parenthesis)

\begin{tabular}{|c|c|c|c|c|}
\hline & (1) & (2) & (3) & (4) \\
\hline & April & May & June & July \\
\hline \multicolumn{5}{|l|}{ Long-distance mobility } \\
\hline \multirow[t]{2}{*}{ Inbound passengers per capita (lag 1 month) } & 0.831 & 0.863 & 0.767 & 0.764 \\
\hline & {$[0.506-1.364]$} & $\begin{array}{l}{[0.529-} \\
1.407]\end{array}$ & $\begin{array}{l}{[0.514-} \\
1.145]\end{array}$ & $\begin{array}{l}{[0.523-} \\
1.115]\end{array}$ \\
\hline \multirow[t]{2}{*}{ Incidence in sending regions (lag 1 month) } & 1.388 & 1.194 & $1.472^{\star \star}$ & 0.849 \\
\hline & {$[0.715-2.693]$} & $\begin{array}{l}{[0.885-} \\
1.612]\end{array}$ & $\begin{array}{l}{[1.161-} \\
1.866]\end{array}$ & $\begin{array}{l}{[0.685-} \\
1.052]\end{array}$ \\
\hline \multirow[t]{2}{*}{ Incidence in sending $\mathrm{x}$ inbound passengers } & 0.964 & 1.089 & 0.884 & 1.031 \\
\hline & {$[0.361-2.576]$} & $\begin{array}{l}{[0.686-} \\
1.727]\end{array}$ & $\begin{array}{l}{[0.643-} \\
1.215]\end{array}$ & $\begin{array}{l}{[0.824-} \\
1.290]\end{array}$ \\
\hline \multirow[t]{2}{*}{ Airport centrality (lag 1 month) } & 1.032 & 0.950 & 0.949 & 0.894 \\
\hline & {$[0.897-1.188]$} & $\begin{array}{l}{[0.836-} \\
1.079]\end{array}$ & $\begin{array}{l}{[0.809-} \\
1.114]\end{array}$ & $\begin{array}{l}{[0.762-} \\
1.050]\end{array}$ \\
\hline \multicolumn{5}{|l|}{ Air travel restrictions (ref: total travel ban) } \\
\hline \multirow{2}{*}{$\begin{array}{l}\text { At most screening and quarantining (lag } 3 \\
\text { weeks) }\end{array}$} & 1.997 & 1.631 & $2.792^{\star \star}$ & 0.646 \\
\hline & {$[0.860-4.639]$} & $\begin{array}{l}{[0.712-} \\
3.735]\end{array}$ & $\begin{array}{l}{[1.318-} \\
5.914]\end{array}$ & $\begin{array}{l}{[0.229-} \\
1.825]\end{array}$ \\
\hline \multirow[t]{2}{*}{ Partial travel ban (lag 3 weeks) } & 0.921 & $0.616^{\star \star}$ & $1.612^{*}$ & $2.249^{\star \star}$ \\
\hline & {$[0.625-1.356]$} & $\begin{array}{l}{[0.427-} \\
0.887]\end{array}$ & $\begin{array}{l}{[1.035-} \\
2.509]\end{array}$ & $\begin{array}{l}{[1.376-} \\
3.674]\end{array}$ \\
\hline \multicolumn{5}{|l|}{ Population mixing (NPI) } \\
\hline \multirow[t]{2}{*}{ Modified stringency index (lag 3 weeks) } & $2.125^{\star \star \star}$ & $1.329^{\star \star}$ & 1.217 & $2.262^{\star \star \star}$ \\
\hline & {$[1.600-2.822]$} & $\begin{array}{l}{[1.118-} \\
1.581]\end{array}$ & $\begin{array}{l}{[0.968-} \\
1.532]\end{array}$ & $\begin{array}{l}{[1.757-} \\
2.913]\end{array}$ \\
\hline \multicolumn{5}{|l|}{ Structural predispositions } \\
\hline Population size (residents) & $27.79^{\star \star \star}$ & $36.55^{\star \star \star}$ & $48.72^{\star \star \star}$ & $22.81^{\star \star *}$ \\
\hline
\end{tabular}

${ }^{*} p<0.05,{ }^{* *} p<0.01,{ }^{* \star *} p<0.001$

Source: Sub-National Covid-19 Incidence and Determinants Dataset 


\begin{tabular}{|c|c|c|c|c|}
\hline & (1) & (2) & (3) & (4) \\
\hline & [13.05-59.15] & $\begin{array}{l}{[17.64-} \\
75.72]\end{array}$ & $\begin{array}{l}{[19.52-} \\
121.6]\end{array}$ & $\begin{array}{l}{[9.987-} \\
52.08]\end{array}$ \\
\hline \multirow[t]{2}{*}{ Real GDP pc PPP } & $1.657^{\star \star \star}$ & $1.761^{\star \star \star}$ & $1.448^{*}$ & $1.437^{\star \star}$ \\
\hline & [1.265-2.171] & $\begin{array}{l}{[1.354-} \\
2.290]\end{array}$ & $\begin{array}{l}{[1.076-} \\
1.948]\end{array}$ & $\begin{array}{l}{[1.108-} \\
1.864]\end{array}$ \\
\hline \multirow[t]{2}{*}{ Population density (pop per km²) } & 1.062 & 1.043 & $1.556^{\star \star \star}$ & 1.160 \\
\hline & [0.869-1.299] & $\begin{array}{l}{[0.861-} \\
1.263]\end{array}$ & $\begin{array}{l}{[1.217-} \\
1.989]\end{array}$ & $\begin{array}{l}{[0.933-} \\
1.442]\end{array}$ \\
\hline \multirow[t]{2}{*}{ Hospital beds per 1000} & $0.554^{\star \star \star}$ & $0.474^{\star \star \star}$ & $0.438^{\star \star \star}$ & $0.411^{\star \star \star}$ \\
\hline & [0.399-0.769] & $\begin{array}{l}{[0.347-} \\
0.648]\end{array}$ & $\begin{array}{l}{[0.301-} \\
0.638]\end{array}$ & $\begin{array}{l}{[0.275-} \\
0.615]\end{array}$ \\
\hline \multirow[t]{2}{*}{ Share of $65+$} & 0.780 & 1.267 & 0.864 & 0.936 \\
\hline & [0.567-1.073] & $\begin{array}{l}{[0.986-} \\
1.628]\end{array}$ & $\begin{array}{l}{[0.624-} \\
1.195]\end{array}$ & $\begin{array}{l}{[0.714-} \\
1.227]\end{array}$ \\
\hline \multirow[t]{2}{*}{ Cardiovascular age-standardized death rate } & $0.532^{\star \star \star}$ & 0.839 & $1.681^{\star}$ & $3.969^{\star \star \star}$ \\
\hline & [0.379-0.746] & $\begin{array}{l}{[0.605-} \\
1.164]\end{array}$ & $\begin{array}{l}{[1.066-} \\
2.652]\end{array}$ & $\begin{array}{l}{[2.590-} \\
6.081]\end{array}$ \\
\hline \multirow[t]{2}{*}{ Cancer age-standardized death rate } & 0.905 & 0.966 & 1.077 & 1.152 \\
\hline & [0.669-1.224] & $\begin{array}{l}{[0.733-} \\
1.274]\end{array}$ & $\begin{array}{l}{[0.742-} \\
1.564]\end{array}$ & $\begin{array}{l}{[0.780-} \\
1.703]\end{array}$ \\
\hline \multirow[t]{2}{*}{ Prevalence of adult obesity } & $3.307^{\star \star \star}$ & 1.126 & 0.786 & $0.400^{*}$ \\
\hline & [1.989-5.498] & $\begin{array}{l}{[0.672-} \\
1.887]\end{array}$ & $\begin{array}{l}{[0.414-} \\
1.491]\end{array}$ & $\begin{array}{l}{[0.197-} \\
0.809]\end{array}$ \\
\hline \multicolumn{5}{|l|}{ Recursive effects } \\
\hline \multirow[t]{2}{*}{ Week of first COVID death } & $0.135^{\star \star \star}$ & $0.482^{\star \star \star}$ & $0.405^{* \star}$ & $0.715^{\star \star \star}$ \\
\hline & $\begin{array}{l}{[0.0752-} \\
0.242]\end{array}$ & $\begin{array}{l}{[0.379-} \\
0.613]\end{array}$ & $\begin{array}{l}{[0.307-} \\
0.533]\end{array}$ & $\begin{array}{l}{[0.611-} \\
0.836]\end{array}$ \\
\hline \multirow[t]{2}{*}{ Lnalpha } & $1.253^{\star \star}$ & $1.214^{\star}$ & $1.708^{\star \star \star}$ & $1.376^{\star \star \star}$ \\
\hline & [1.066-1.472] & $\begin{array}{l}{[1.045-} \\
1.409]\end{array}$ & $\begin{array}{l}{[1.452-} \\
2.010]\end{array}$ & $\begin{array}{l}{[1.152-} \\
1.644]\end{array}$ \\
\hline Observations & 361 & 361 & 361 & 361 \\
\hline Pseudo R-squared & 0.177 & 0.131 & 0.107 & 0.138 \\
\hline \multicolumn{5}{|l|}{${ }^{*} p<0.05,{ }^{* *} p<0.01,{ }^{* \star *} p<0.001$} \\
\hline Sou & & & & \\
\hline
\end{tabular}




\begin{tabular}{|lllll|}
\hline & (1) & (2) & (3) & (4) \\
\hline Continent Fixed Effects & Yes & Yes & Yes & Yes \\
\hline${ }^{*} p<0.05,{ }^{* \star} p<0.01,{ }^{* \star} p<0.001$ & & & & \\
\hline Source: Sub-National Covid-19 Incidence and Determinants Dataset & & \\
\hline
\end{tabular}

\section{Weekly incidence: modeling by epidemiological weeks}

The previous analyses treated Covid-19 mortality by calendar weeks of the year 2020. In this section we repeat them aligning data by epidemiological week (i.e., the week since the first Covid-19 death) instead, thus following the evolution of the pandemic (Table 4), regardless of the different timing of the spread of the virus across the world in the first semester of 2020 . We focus on the eighteen weeks immediately after the outbreak, with a view to further test $\mathrm{H} 3$ on the changing impact of long-distance travel over time.

Table 4 reports results for epidemiological weeks $6,10,14$ and 18 . In line with previous studies ${ }^{38}$, our findings still show an impact of total travel bans, which peaks at week 14 only to decline at week 18 . Partial travel bans (mostly from China) do equally buffer incidence at the very early stage but end up being almost as ineffective as milder passenger monitoring measures. As weeks pass by, it is total travel bans that more clearly reduce mortality. The interaction term between 'passenger volume' and 'average incidence in the area of origin of passengers' never reaches statistical significance. Notably, the effect does not disappear with the passing of time, as posited by $\mathrm{H} 3$, and as we might expect given the progressively increasing controls on travelers' health at departure. Its magnitude remains relatively modest, while other factors - notably, the precocity of the outbreak are way more effective in explaining differences in the mortality of Covid-19 at all stages. The effects of structural factors diverge somehow from what was shown in the analysis based on calendar weeks. Richer areas are significantly more at risk in the early weeks, but this effect is reverted over time, as these areas can deploy more resources to contrast the disease. With time, population density becomes an increasingly impactful risk factor. The prevalence of obesity and a larger share of the senior population have a declining effect. This is quite surprising but it may reflect the fact that areas with a higher share of overweight individuals and people ages 65 or more were disproportionately hit in the earlier stages of the pandemic. The opposite trajectory is found for areas with higher cardiovascular death rates, which are subject to the rising severity of Covid-19. The number of hospital beds - a proxy of the solidity of the health system - is in fact a constant and rising predictor of lower mortality. 
Table 4

The impact of air passenger traffic on the severity of Covid-19 mortality in the first 18 epidemiological weeks (week1=first Covid-19 death) controlling for population mixing (NPI), structural predispositions and recursive effects. Negative binomial regressions with continent fixed effects. Risk ratios and confidence intervals (in parenthesis)

\begin{tabular}{|c|c|c|c|c|}
\hline & (1) & (2) & (3) & (4) \\
\hline & Epi wk 6 & Epi wk 10 & Epi wk 14 & Epi wk 18 \\
\hline \multicolumn{5}{|l|}{ Long-distance mobility } \\
\hline \multirow[t]{2}{*}{ Inbound passengers per capita (lag 1 month) } & 0.982 & 0.748 & 0.807 & 0.579 \\
\hline & $\begin{array}{l}{[0.777-} \\
1.242]\end{array}$ & $\begin{array}{l}{[0.511-} \\
1.094]\end{array}$ & $\begin{array}{l}{[0.606-} \\
1.075]\end{array}$ & $\begin{array}{l}{[0.335-} \\
1.000]\end{array}$ \\
\hline \multirow[t]{2}{*}{ Incidence in sending regions (lag 1 month) } & 1.269 & 0.951 & 1.119 & 1.033 \\
\hline & $\begin{array}{l}{[0.946-} \\
1.701]\end{array}$ & $\begin{array}{l}{[0.771-} \\
1.172]\end{array}$ & $\begin{array}{l}{[0.885-} \\
1.415]\end{array}$ & $\begin{array}{l}{[0.765-} \\
1.395]\end{array}$ \\
\hline \multirow[t]{2}{*}{ Incidence in sending $\mathrm{x}$ inbound passengers } & 0.915 & 1.061 & 1.044 & 1.426 \\
\hline & $\begin{array}{l}{[0.662-} \\
1.264]\end{array}$ & $\begin{array}{l}{[0.781-} \\
1.441]\end{array}$ & $\begin{array}{l}{[0.888-} \\
1.227]\end{array}$ & $\begin{array}{l}{[0.972-} \\
2.094]\end{array}$ \\
\hline \multirow[t]{2}{*}{ Airport centrality (lag 1 month) } & 1.105 & 1.043 & 0.898 & 0.984 \\
\hline & $\begin{array}{l}{[0.873-} \\
1.398]\end{array}$ & $\begin{array}{l}{[0.868-} \\
1.253]\end{array}$ & $\begin{array}{l}{[0.775-} \\
1.041]\end{array}$ & $\begin{array}{l}{[0.872-} \\
1.111]\end{array}$ \\
\hline \multicolumn{5}{|l|}{ Air travel restrictions (ref: total travel ban) } \\
\hline \multirow{2}{*}{$\begin{array}{l}\text { At most screening and quarantining (lag } 3 \\
\text { weeks) }\end{array}$} & 2.280 & 1.502 & $4.556^{\star \star \star}$ & 1.256 \\
\hline & $\begin{array}{l}{[0.955-} \\
5.443]\end{array}$ & $\begin{array}{l}{[0.633-} \\
3.563]\end{array}$ & $\begin{array}{l}{[2.010-} \\
10.33]\end{array}$ & $\begin{array}{l}{[0.589-} \\
2.678]\end{array}$ \\
\hline \multirow[t]{2}{*}{ Partial travel ban (lag 3 weeks) } & $0.525^{\star *}$ & 1.076 & $2.988^{\star \star \star}$ & 1.621 \\
\hline & $\begin{array}{l}{[0.352-} \\
0.782]\end{array}$ & $\begin{array}{l}{[0.746-} \\
1.552]\end{array}$ & $\begin{array}{l}{[1.720-} \\
5.192]\end{array}$ & $\begin{array}{l}{[0.968-} \\
2.714]\end{array}$ \\
\hline \multicolumn{5}{|l|}{ Population mixing (NPI) } \\
\hline \multirow[t]{2}{*}{ Modified stringency index (lag 3 weeks) } & 0.921 & $1.289^{*}$ & 1.038 & 1.016 \\
\hline & $\begin{array}{l}{[0.771-} \\
1.100]\end{array}$ & $\begin{array}{l}{[1.052-} \\
1.578]\end{array}$ & $\begin{array}{l}{[0.981-} \\
1.098]\end{array}$ & $\begin{array}{l}{[0.988-} \\
1.045]\end{array}$ \\
\hline \multicolumn{5}{|l|}{ Structural predispositions } \\
\hline \multirow[t]{2}{*}{ Population size (residents) } & $12.89^{\star \star \star}$ & $23.24^{\star \star \star}$ & $18.48^{\star \star \star}$ & $17.78^{\star \star \star}$ \\
\hline & $\begin{array}{l}{[5.822-} \\
28.53]\end{array}$ & $\begin{array}{l}{[10.74-} \\
50.25]\end{array}$ & $\begin{array}{l}{[7.821-} \\
43.67]\end{array}$ & $\begin{array}{l}{[7.093-} \\
44.56]\end{array}$ \\
\hline
\end{tabular}

${ }^{\star} p<0.05,{ }^{* \star} p<0.01,{ }^{* \star \star} p<0.001$. Source: Sub-National Covid-19 Incidence and Determinants Dataset 


\begin{tabular}{|c|c|c|c|c|}
\hline & (1) & (2) & (3) & (4) \\
\hline \multirow[t]{2}{*}{ Real GDP pc PPP } & $1.289^{*}$ & 1.237 & 0.987 & $0.734^{\star *}$ \\
\hline & $\begin{array}{l}{[1.023-} \\
1.624]\end{array}$ & $\begin{array}{l}{[0.999-} \\
1.530]\end{array}$ & $\begin{array}{l}{[0.791-} \\
1.232]\end{array}$ & $\begin{array}{l}{[0.585-} \\
0.921]\end{array}$ \\
\hline \multirow[t]{2}{*}{ Population density (pop per km²) } & 1.066 & $1.304^{*}$ & $1.391^{\star *}$ & $1.389^{\star *}$ \\
\hline & $\begin{array}{l}{[0.854-} \\
1.332]\end{array}$ & $\begin{array}{l}{[1.044-} \\
1.627]\end{array}$ & $\begin{array}{l}{[1.094-} \\
1.769]\end{array}$ & $\begin{array}{l}{[1.084-} \\
1.779]\end{array}$ \\
\hline \multirow[t]{2}{*}{ Hospital beds per 1000} & $0.567^{* \star}$ & $0.433^{* * *}$ & $0.375^{\star \star \star}$ & $0.313^{* \star \star}$ \\
\hline & $\begin{array}{l}{[0.400-} \\
0.802]\end{array}$ & $\begin{array}{l}{[0.308-} \\
0.609]\end{array}$ & $\begin{array}{l}{[0.243-} \\
0.578]\end{array}$ & $\begin{array}{l}{[0.196-} \\
0.500]\end{array}$ \\
\hline \multirow[t]{2}{*}{ Share of $65+$} & 0.835 & 0.864 & $0.553^{\star \star \star}$ & $0.649^{\star *}$ \\
\hline & $\begin{array}{l}{[0.627-} \\
1.111]\end{array}$ & $\begin{array}{l}{[0.660-} \\
1.131]\end{array}$ & $\begin{array}{l}{[0.418-} \\
0.730]\end{array}$ & $\begin{array}{l}{[0.485-} \\
0.869]\end{array}$ \\
\hline \multirow[t]{2}{*}{ Cardiovascular age-standardized death rate } & 1.425 & $1.680^{\star \star}$ & $4.899^{\star \star \star}$ & $2.938^{\star \star \star}$ \\
\hline & $\begin{array}{l}{[0.928-} \\
2.186]\end{array}$ & $\begin{array}{l}{[1.150-} \\
2.454]\end{array}$ & $\begin{array}{l}{[3.111-} \\
7.714]\end{array}$ & $\begin{array}{l}{[1.995-} \\
4.326]\end{array}$ \\
\hline \multirow[t]{2}{*}{ Cancer age-standardized death rate } & 0.859 & 0.850 & 1.310 & 1.027 \\
\hline & $\begin{array}{l}{[0.618-} \\
1.195]\end{array}$ & $\begin{array}{l}{[0.611-} \\
1.183]\end{array}$ & $\begin{array}{l}{[0.855-} \\
2.008]\end{array}$ & $\begin{array}{l}{[0.643-} \\
1.643]\end{array}$ \\
\hline \multirow[t]{2}{*}{ Prevalence of adult obesity } & 1.538 & 1.085 & $0.389^{\star \star}$ & 0.844 \\
\hline & $\begin{array}{l}{[0.884-} \\
2.676]\end{array}$ & $\begin{array}{l}{[0.629-} \\
1.870]\end{array}$ & $\begin{array}{l}{[0.199-} \\
0.760]\end{array}$ & $\begin{array}{l}{[0.399-} \\
1.783]\end{array}$ \\
\hline \multicolumn{5}{|l|}{ Recursive effects } \\
\hline \multirow[t]{2}{*}{ Week of first COVID death } & $0.517^{\star \star \star}$ & $0.675^{\star \star \star}$ & $0.617^{\star \star \star}$ & $0.720^{\star \star \star}$ \\
\hline & $\begin{array}{l}{[0.445-} \\
0.601]\end{array}$ & $\begin{array}{l}{[0.590-} \\
0.771]\end{array}$ & $\begin{array}{l}{[0.537-} \\
0.709]\end{array}$ & $\begin{array}{l}{[0.618-} \\
0.839]\end{array}$ \\
\hline \multirow[t]{2}{*}{ Lnalpha } & $1.409^{\star \star \star}$ & $1.250^{\star *}$ & $1.502^{\star \star \star}$ & $1.526^{\star \star}$ \\
\hline & $\begin{array}{l}{[1.211-} \\
1.639]\end{array}$ & $\begin{array}{l}{[1.067-} \\
1.465]\end{array}$ & $\begin{array}{l}{[1.265-} \\
1.784]\end{array}$ & $\begin{array}{l}{[1.274-} \\
1.828]\end{array}$ \\
\hline Observations & 357 & 357 & 357 & 357 \\
\hline Pseudo R-squared & 0.125 & 0.116 & 0.122 & 0.123 \\
\hline Continent Fixed Effects & Yes & Yes & Yes & Yes \\
\hline
\end{tabular}




\section{Discussion}

As an airborne disease, Covid-19 has spread worldwide through human travel. Our analyses have inquired whether such spread - or, more precisely, the timing and strength of its effect on mortality rates - was systematically linked to the size of passenger flows and the connectedness of sub-national areas worldwide through airline routes in the first semester of 2020 . We found this to be only partially the case. As regards the precocity of the emergence of Covid-19 as a cause of death, airport centrality is not at all significant and the volume of air passengers is found to be only a concomitant factor, with other structural predispositions being more strongly impactful. Results are somewhat less straightforward when it comes to the severity of the virus' death toll. The network centrality of airports and the volume of air travelers are at no point significant predictors neither in a calendar week nor in an epidemiological week analytical framework. However, further insights emerge when we dig deeper into the impact of air travel limitations. Such measures are particularly controversial, not the least because they challenge the International Health Regulations (IHR), a pact on collective action, which says that health measures implemented by countries "shall not be more restrictive of international traffic and not more invasive or intrusive to persons than reasonably available alternatives" 39 . The symbolic impact of border closure as a form of externalization of the costs of pandemic control - perceived by some as targeting political consensus more than public health benefits - has to be factored in as well ${ }^{40}$. Bearing this in mind, our results suggest that more draconian travel limitation policies might have been effective in cutting Covid-19 mortality, and slightly more so with the passing of time, as shown by distinct week by week analyses. From this finding we evince that, when maintained, air travel - regardless of the number of incoming passengers - does contribute to feeding the pandemic, alongside self-reproductive dynamics in situ once the virus is imported ${ }^{41,42}$.

Overall, these findings do not corroborate our initial hypotheses, but qualify them. In other words, our results suggest that the impact of long-distance mobility approximates an 'All-or-None Principle' whereby the absence of air travel reduces radically epidemic risk. However, once some travel occurs its impact on the severity of the pandemic is only modestly associated with the volume of incoming passengers and the centrality of airports in the global network of commercial flights. This is possibly because once the infection lands into an area, the harm it causes is largely driven by within-area determinants of further spread. In this sense, local transmission outweighs importation risk. The combination of the high relevance of full travel bans and the low relevance of the volume of travel as determinants of Covid-19 mortality risk is the main takeaway of our analysis.

While existing research on the nexus between travel and the spread of Covid-19 is mostly based on simulations, which are known to face major problems in the case of complex events like pandemics ${ }^{43,44}$, we drew on actual, real-life data on both airline passengers and virus mortality on a large geographical scale. Our analyses, though, have a number of limitations that we acknowledge. First, our units are sub-national areas of different size, in terms of population and surface. Second, our main dependent variable - the weekly incidence of Covid-19 deaths - is far from perfect, as the imputation of deaths to the virus was not harmonized with a standard protocol across the board in all of the areas we covered, especially in cases of comorbidity and in the early stages of the pandemic ${ }^{45}$. Some of our independent variables suffer from limitations as well. While very detailed, data about air passengers account for only a part of long-haul human mobility. People also travel across localities by train, bus, car and boats. Moreover, in absence of more granular information, we impute national data about comorbidities to our subnational areas, assuming little variations country-wide, which may not always be the case. This may inflate error terms in our estimates. Another limit relates to time: our analysis is 
restricted to the first half of 2020, while the pandemic unfolded well beyond this period. Finally, although we have an unprecedented coverage of areas hit by the virus, they are mostly in developed parts of the world. This may have led us to underestimate other potential conditions boosting the severity of the disease (notably, poverty ${ }^{46}$. Future research should address these limitations to get an even more robust assessment of the impact of human travel on the precocity and severity of the pandemic globally.

\section{Declarations}

\section{Data availability}

The dataset created for this article is publicly available in the Harvard Dataverse repository: https://doi.org/10.7910/DVN/SEGOVA.

\section{Code availability}

The code implementing the model is available from the corresponding author on reasonable request.

\section{Acknowledgements}

Research presented in this article was supported by the European University Institute (EUI), Covid-related grant ("The Airport Factor: Assessing the Impact of International and National Aviation Mobility on the Spread of Covid$19^{\prime \prime}$, project submitted by the Migration Policy Centre).

\section{Author information}

E.R. developed the idea, coordinated the research project and wrote the first draft of the manuscript. A.F., A.R.S., L.G., L.B., S.I., S.S. and M.V. collected and validated the data. A.F., A.R.S., E.D., S.I., L.G., L.B. and E.R. conducted the statistical analyses. All authors discussed the results and edited the final manuscript. Corresponding author: ettore.recchi@eui.eu

\section{References}

1. Tatem, A. J., Rogers, D. \& Hay, S. I. Global transport networks and infectious disease spread. Advances in Parasitology. 62, 294-333; https://doi.org/10.1016/S0065-308X(05)62009-X (2006)

2. Balcan, D. et al. Multiscale mobility networks and the spatial spreading of infectious disease. Proceedings from the National Academy of Science. 106(51), 21484-21489; https://doi.org/10.1073/pnas.0906910106 (2009)

3. 3Aniruddha, A. et al. Interplay of global multi-scale human mobility, social distancing, government interventions, and COVID-19 dynamics. Preprint at https://doi.org/10.1101/2020.06.05.20123760 (2020)

4. Askitas, N., Tatsiramos, K. \& Verheyden, B. Estimating worldwide effects of non-pharmaceutical interventions on COVID-19 incidence and population mobility patterns using a multiple-event study. Scientific reports. 11(1), 1-13; https://doi.org/10.1038/s41598-021-81442-x (2021)

5. Flaxman, S. et al. Estimating the effects of non-pharmaceutical interventions on COVID-19 in Europe. Nature. 584(7820), 257-261; https://doi.org/10.1038/s41586-020-2405-7 (2020) 
6. Brockmann, D. \& Helbing, D. The hidden geometry of complex, network-driven contagion phenomena. Science. 342(6164), 1337-1342; 10.1126/science.1245200 (2013)

7. Vespignani, A. Predicting the behavior of techno-social systems. Science. 325(5939), 425-428; 10.1126/science.1171990 (2009)

8. Pastor-Satorras, R., Castellano, C., Mieghem, P. V. \& Vespignani, A. Epidemic processes in complex networks. Reviews of Modern Physics. 87, 925; https://doi.org/10.1103/RevModPhys.87.925 (2015)

9. Balcan, D. et al. Multiscale mobility networks and the spatial spreading of infectious diseases. Proceedings from the National Academy of Science. 106(51), 21484-21489; https://doi.org/10.1073/pnas.0906910106 (2009)

10. Junling, M. \& Earn, D. J. D. Generality of the final size formula for an epidemic of a newly invading infectious disease. Bulletin of Mathematical Biology, 68, 679-702; https://doi.org/10.1007/s11538-005-9047-7 (2006)

11. Ferguson, N. M. et al. Strategies for mitigating an influenza pandemic. Nature. 442, 448-452; https://doi.org/10.1038/nature04795 (2006)

12. Mateus, A. L. P., Otete, H. E., Beck, C. R., Dolan, G. P. \& Nguyen-Van-Tam, J. S. Effectiveness of travel restrictions in the rapid containment of human influenza: a systematic review. Bulletin of the World Health Organization, 92, 868-880D; http://dx.doi.org/10.2471/BLT.14.135590 (2014)

13. Clemens, M. A. \& Ginn, T. Global mobility and the threat of pandemics: evidence from three centuries. IZA Discussion Paper No. 13947; https://ssrn.com/abstract=3751840 (2020)

14. He, X. et al. Temporal dynamics in viral shedding and transmissibility of COVID-19. Nature Medicine. 26, 672-675; https://doi.org/10.1038/s41591-020-0869-5 (2020)

15. Kraemer, M. U. G. et al. The effect of human mobility and control measures on the COVID-19 epidemic in China. Science. 368(6490), 493-497; 10.1126/science.abb4218 (2020)

16. Farzanegan, M. R., Gholipour, H. F., Feizi, M., Nunkoo, R. \& Andargoli, A. E. International tourism and outbreak of coronavirus (COVID-19): A cross-country analysis. Journal of Travel Research. 60(3), 687-692; https://doi.org/10.1177/0047287520931593 (2021)

17. Oztig, L. I. \& Askin, O. E. Human mobility and coronavirus disease 2019 (COVID-19): a negative binomial regression analysis. Public Health. 185, 364-367; https://doi.org/10.1016/j.puhe.2020.07.002 (2020)

18. Chinazzi, M. et al. The effect of travel restrictions on the spread of the 2019 novel coronavirus (COVID-19) outbreak. Science, 368(6489), 395-400; 10.1126/science.aba9757 (2020)

19. Anzai, A. et al. Assessing the impact of reduced travel on exportation dynamics of novel coronavirus infection (COVID-19). Journal of clinical medicine. 9(2), 601; https://doi.org/10.3390/jcm9020601 (2020)

20. Linka, K., Peirlinck, M., Sahli Costabal, F. \& Kuhl, E. Outbreak dynamics of COVID-19 in Europe and the effect of travel restrictions. Computer Methods in Biomechanics and Biomedical Engineering. 23(11), 710-717; https://doi.org/10.1080/10255842.2020.1759560 (2020)

21. Wells, C. R. et al. Impact of international travel and border control measures on the global spread of the novel 2019 coronavirus outbreak. Proceedings of the National Academy of Science. 117(13), 7504-7509; https://doi.org/10.1073/pnas.2002616117 (2020)

22. Nakamura, H. \& Managi, S. Airport risk of importation and exportation of the COVID-19 pandemic. Transport Policy. 96, 40-47. https://doi.org/10.1016/j.tranpol.2020.06.018 (2020) 
23. Russell, T. W. et al. Effect of internationally imported cases on internal spread of COVID-19: a mathematical modelling study. The Lancet Public Health. 6(1), e12-e20; https://doi.org/10.1016/S2468-2667(20)30263-2 (2021)

24. Aleta, A., Hu, Q., Ye, J., Ji, P. \& Moreno, Y. A data-driven assessment of early travel restrictions related to the spreading of the novel COVID-19 within mainland China. Chaos, Solitons \& Fractals. 139, 110068; https://doi.org/10.1016/j.chaos.2020.110068 (2020)

25. Sorci, G., Faivre, B. \& Morand, S. Explaining among-country variation in COVID-19 case fatality rate. Scientific reports. 10(1), 1-11; https://doi.org/10.1038/s41598-020-75848-2 (2020)

26. Chaudhry, R., Dranitsaris, G., Mubashir, T., Bartoszko, J. \& Riazi, S. (2020). A country level analysis measuring the impact of government actions, country preparedness and socioeconomic factors on COVID-19 mortality and related health outcomes. EClinicalMedicine. 25, 100464; https://doi.org/10.1016/j.eclinm.2020.100500 (2020)

27. Knittel, C. R. \& Ozaltun, B. What does and does not correlate with COVID-19 death rates. NBER working paper $27391 ; 10.3386 /$ w27391 (2020)

28. Wu, X., Nethery, R. C., Sabath, M. B., Braun, D. \& Dominici, F. Air pollution and COVID-19 mortality in the United States: Strengths and limitations of an ecological regression analysis. Science advances. 6(45), eabd4049; $10.1126 /$ sciadv.abd4049 (2020)

29. Alfano, V. \& Ercolano, S. The efficacy of lockdown against COVID-19: a cross-country panel analysis. Applied health economics and health policy. 18, 509-517; https://doi.org/10.1007/s40258-020-00596-3 (2020)

30. Haug, N. et al. Ranking the effectiveness of worldwide COVID-19 government interventions. Nature human behaviour. 4(12),1303-1312; https://doi.org/10.1038/s41562-020-01009-0 (2020)

31. Brauner, J. M. et al. Inferring the effectiveness of government interventions against COVID-19. Science. 371(6531), eabd9338, 10.1126/science.abd9338 (2021)

32. Hale, T. et al. A global panel database of pandemic policies (Oxford COVID-19 Government Response Tracker). Nature Human Behaviour. 5(4), 529-538; https://doi.org/10.1038/s41562-021-01079-8 (2021)

33. Santamaria, C. et al. Measuring the impact of COVID-19 confinement measures on human mobility using mobile positioning data. A European regional analysis. Safety Science. 132, 104925; https://doi.org/10.1016/j.ssci.2020.104925 (2020)

34. García-García, D. et al. Retrospective methodology to estimate daily infections from deaths (REMEDID) in COVID-19: the Spain case study. Scientific reports, 11(1), 1-15; https://doi.org/10.1038/s41598-021-90051-7 (2021)

35. Irons, N. J., Raftery, A. E. \& Estimating SARS-CoV-2 Infections from Deaths, Confirmed Cases, Tests, and Random Surveys. Proceedings from the National Academy of Science. 118 (31), e2103272118; https://doi.org/10.1073/pnas.2103272118 (2021)

36. Cottarelli, C. \& Paudice, F. Perché il Covid-19 ha colpito i paesi in modo diverso? Working Paper Università Cattolica di Milano. Available at https://osservatoriocpi.unicatt.it/cpi-mortalit\%c3\%a0.pdf (2021)

37. Gelman, A. \& Hill, J. Data analysis using regression and multilevel/hierarchical models. (Cambridge University Press 2006)

38. Wilson, N., Baker, M. G., Blakely, T. \& Eichner, M. Estimating the impact of control measures to prevent outbreaks of COVID-19 associated with air travel into a COVID-19-free country. Scientific reports. 11(1), 1-9; 
https://doi.org/10.1038/s41598-021-89807-y (2021)

39. Devi, S. Travel restrictions hampering COVID-19 response. The Lancet. 395(10233), 1331-1332; https://doi.org/10.1016/S0140-6736(20)30967-3 (2020)

40. Kenwick, M. R. \& Simmons, B. A. Pandemic response as border politics. International Organization. 74(S1), E36-E58; 10.1017/S0020818320000363 (2020)

41. Chu, A. M., Tsang, J. T., Chan, J. N., Tiwari, A. \& So, M. K. Analysis of travel restrictions for COVID-19 control in Latin America through network connectedness. Journal of travel medicine. 27(8), taaa176; https://doi.org/10.1093/jtm/taaa176 (2020)

42. Nakamura, H. \& Managi, S. Airport risk of importation and exportation of the COVID-19 pandemic. Transport Policy. 96, 40-47; https://doi.org/10.1016/j.tranpol.2020.06.018 (2020)

43. Ioannidis, J. P. A., Cripps, S. \& Tanner, M. A. Forecasting for COVID-19 has failed. International Journal of Forecasting. https://doi.org/10.1016/j.ijforecast.2020.08.004 (2020)

44. Prasse, B., Achterberg, M. A. \& Van Mieghem, P. and Fundamental Limits of Predicting Epidemic Outbreaks. Technical Report report 2020410 Delft University of Technology. Available at https://www.nas.ewi.tudelft.nl/people/Piet/papers/TUD2020410_prediction_limits_epidemic_outbreaks.pdf (2020)

45. Garcia, J. et al. Differences in COVID-19 mortality: Implications of imperfect and diverse data collection systems. Population. 76(1), 35-72; https://doi.org/10.3917/popu.2101.0037 (2021)

46. Yechezkel, M. et al. Human mobility and poverty as key drivers of COVID-19 transmission and control. BMC public health, 21(1), 1-13; https://doi.org/10.1186/s12889-021-10561-x (2021)

\section{Figures}



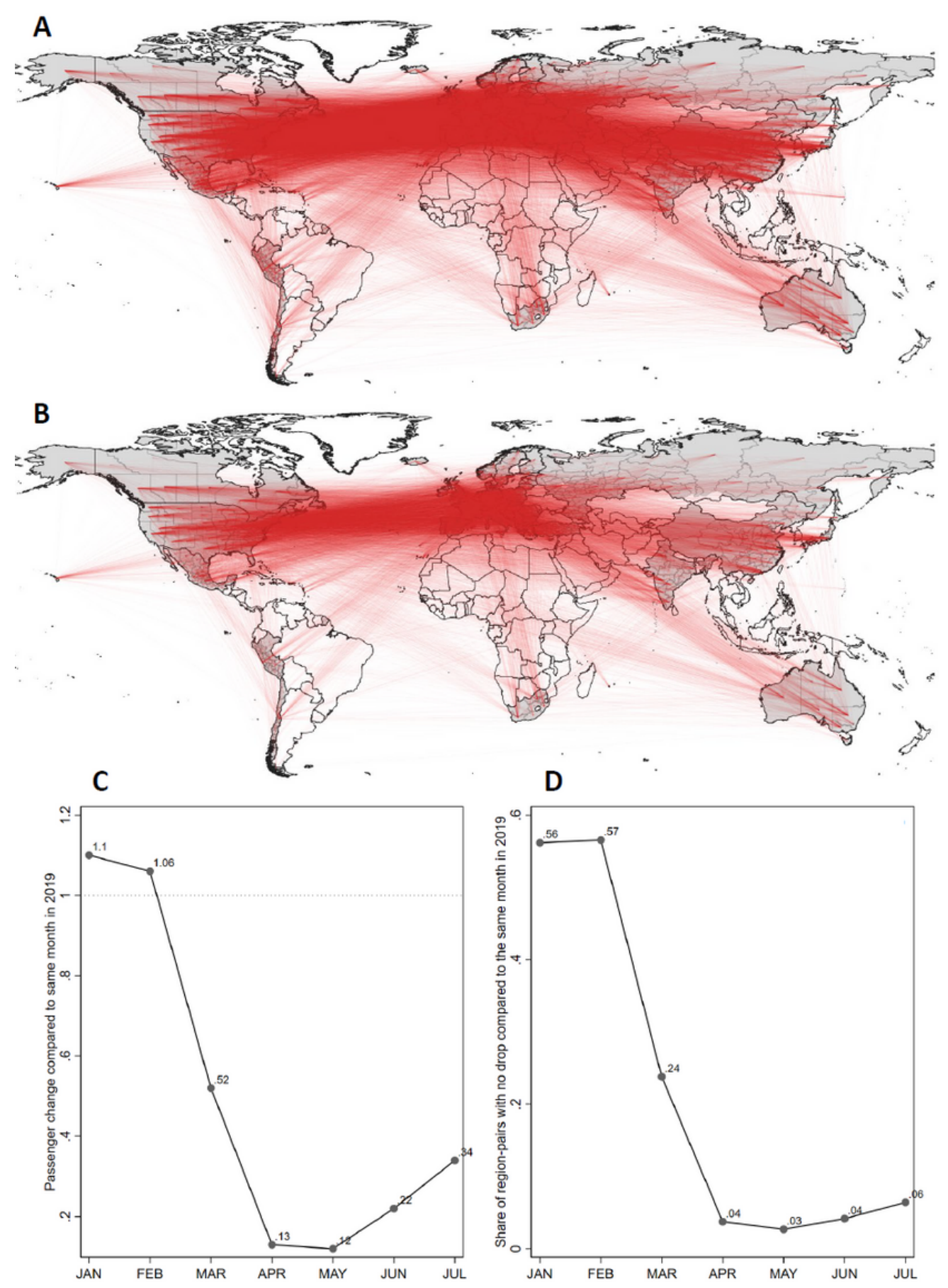

\section{Figure 1}

The COVID-19-induced drop in global air traffic Note: Panel A shows active airline routes between the subnational areas included in our dataset in April 2019; panel B shows the situation one year later, in April 2020. Each line includes routes from all airports of the area. Panel $\mathrm{C}$ shows the average change in the monthly number of air passengers in 2020 compared to 2019 (with a value smaller than 1 indicating a drop in passengers). Panel D shows the share of region-pairs that saw no drop in air passenger traffic in 2020 compared to the same month in 2019. A drop is defined here as the number of passengers reaching 90 per cent or less of the value in the previous year (assuming that a drop of less than 10 per cent is not meaningful and may just indicate random fluctuation). Source: Sub-National Covid-19 Incidence and Determinants Dataset. 


\section{Supplementary Files}

This is a list of supplementary files associated with this preprint. Click to download.

- SIACaseofAllorNoneOct132021.pdf 